\title{
KETANGGUHAN SISTEM EKONOMI ISLAM DALAM PEREKONOMIAN DUNIA
}

\author{
Oleh: Windari \\ Dosen Jurusan Ekonomi Syariah Fakultas Ekonomi dan Bisnis Islam \\ IAIN Padangsidimpuan
}

\begin{abstract}
Goals to be achieved in the activities of this paper to see toughness Islamic economics in the world economy. Due to bad the world economy today which is easy to be swayed by speculators. The study of literature is a major source, regarding various provisions of the studies that have been done before, and is supported by a study published by various agencies in the form of journals and other scientific studies. Islamic economics is a solution for mankind to come out of the crisis and prosper, besides that Islamic economics offers an Islamic economic system built on the foundation of the Islamic faith.
\end{abstract}

Keywords: Capitalist, Socialist, Communist, Fascism, Islamic Economics

\section{A. Pendahuluan}

Suatu organisasi dalam persaingan bebas sekarang ini harus memahami situasi bisnis yang sedang berlangsung. Perubahan yang yang cepat dalam lingkungan menuntut organisasi tanggap atas lingkungan disekitarnya. Situasi ini menuntut kesiapan yang lebih matang dalam segala hal khususnya dalam hal mengkondisikan organisasi untuk merumuskan strategi agar mampu mengantisipasi perubahan dan pencapaian tujuan tersebut dan dapat menyeimbangkan pencapaian yang diharapkan sebelumnya.

Ekonomi Islam Sistem perekonomian yang meliputi sistem perbankan, pasar modal, asuransi, dana pensiun, multifinance dan infrastruktur lainnya yang saling berinteraksi dalam memobilisasi suatu perekonomian suatu Negara. Berbagai negara memilki suatu paham sistem perekonomian yang berbeda, Perbedaan ini tidak terlepas dari pengaruh filsafat, agama, ideologi, dan kepentingan politik yang mendasari suatu negara penganut sistem tersebut.

Dari sekian banyak sistem perekonomian dimuka bumi ini tidak ada diantara sistem ekonomi yang diterapkan secara penuh berhasil. Sistem ekonomi sosialis hancur dengan bubarnya Uni soviet, kapitalis membawa akibat negatif dan lebih buruk karena banyak Negara miskin semakin miskin dan yang kaya semakin kaya, hal ini disebabkan 
karena sistem tersebut lebih menonjolkan kelemahan dan kekurangannya ketimbang keuntungannya.

Karena kelemahannya dan kekurangannya lebih menonjol maka timbullah pemikiran baru tentang sistem ekonomi Islam yang dipelopori oleh Negara-negara Islam atau yang mayoritas penduduknya Islam, yang menjadikan sistem ekonomi ini sebagai alternative bagi sistem kapitalisme. Selain dari itu sistem ekonomi berkaitan juga dengan falsafah, pandangan pola hidup masyarakat. Sebuah sistem ekonomi susungguhnya merupakan salah satu unsur saja dalam suatu suprasistem kehidupan masyarakat. Sistem ekonomi adalah suatu sistem yang mengatur serta menjalin hubungan ekonomi antara manusia dengan seperangkat kelembagaan dalam suatu tatanan kehidupan. ${ }^{1}$

Kegiatan ekonomi merupakan sesuatu yang tidak bisa dipisahkan dalam kehidupan manusia. Kegiatan yang berupa produksi, distribusi dan konsumsi ini dilakukan dalam rangka memenuhi seluruh kebutuhan hidup manusia. Setiap tindakan manusia didasarkan pada keinginanannya untuk memenuhi kebutuhan hidup. Dimana Aktivitas ekonomi inipun dimulai dari zaman nabi Adam hingga detik ini, meskipun dari zaman ke zaman mengalami perkembangan. Setiap masa manusia mencari cara untuk mengembangkan proses ekonomi ini sesuai dengan tuntuan kebutuhannya.

\section{B. Pembahasan}

\section{Sistem Perekonomian}

Pemikiran-pemikiran ekonomi yang berkembang saat ini telah mengalami suatu proses yang panjang. Perkembangannya berlangsung berabad-abad seiring dengan munculnya peradaban-peradaban yang ada di dunia. Bahkan pemikiran tersebut mulai tampak sejak zaman batu, perunggu, dan besi. Kemudian semakin berkembang sejak ditemukannya tulisan pada peradaban India kuno, Mesir kuno, dan Babylonia. Sedangkan barat lebih cenderung pada peradaban Yunani kuno yang kaya akan peninggalan dari kaum intelektualnya. ${ }^{2}$

Dalam hal ini dapat dilihat bagaimana pemikiran-pemikiran awal tentang ekonomi, sebelum ilmu ekonomi itu sendiri mendapat pengakuan sebagai cabang ilmu tersendiri. Salah satu corak perkembangan pemikiran ekonomi pada masa lampau adalah kegiatan bisnisnya yang menggunakan sistem bunga. Para pakar sejarah pemikiran ekonomi menyimpulkan bahwa kegiatan bisnis dengan sistem bunga telah ada sejak tahun 2500 sebelum masehi, baik di Yunani kuno, Romawi kuno, dan Mesir kuno. Pada tahun 2000 sebelum masehi, di Mesopotamia (wilayah Iraq sekarang), telah berkembang sistem bunga. ${ }^{3}$ Pada beberapa sistem perekonomian kapitalis dibawah ini: 


\section{a. Kapitalis}

Kapitalisme berasal dari Inggris abad 18, kemudian menyebar ke Eropa Barat dan Amerika Utara. Sebagai akibat dari perlawanan terhadap ajaran gereja, tumbuh aliran pemikiran liberalisme di negara-negara Eropa Barat. Aliran ini kemudian merambah ke segala bidang termasuk bidang ekonomi.

Dasar filosofis pemikiran ekonomi Kapitalis bersumber dari tulisan Adam Smith dalam bukunya An Inquiry into the Nature and Causes of the Wealth of Nations yang ditulis pada tahun 1776. Isi buku tersebut sarat dengan pemikiranpemikiran tingkah laku ekonomi masyarakat. Dari dasar filosofi tersebut kemudian menjadi sistem ekonomi, dan pada akhirnya kemudian mengakar menjadi ideologi yang mencerminkan suatu gaya hidup (way of life).

Smith berpendapat motif manusia melakukan kegiatan ekonomi adalah atas dasar dorongan kepentingan pribadi, yang bertindak sebagai tenaga pendorong yang membimbing manusia mengerjakan apa saja asal masyarakat sedia membayar "Bukan berkat kemurahan tukang daging, tukang pembuat bir, atau tukang pembuat roti kita dapat makan siang," kata Smith "akan tetapi karena mereka memperhatikan kepentingan pribadi mereka. Kita berbicara bukan kepada rasa perikemanusiaan mereka, melainkan kepada cinta mereka kepada diri mereka sendiri, dan janganlah sekali-kali berbicara tentang keperluan-keperluan kita, melainkan tentang keuntungan-keuntungan mereka. ${ }^{\text {it }}$

Dalam sistem ekonomi kapitalis berlaku "Free Fight Liberalism" (sistem persaingan bebas). Siapa yang memiliki dan mampu menggunakan kekuatan modal (Capital) secara efektif dan efisien akan dapat memenangkan pertarungan dalam bisnis. Paham yang mengagungkan kekuatan modal sebagai syarat memenangkan pertarungan ekonomi disebut sebagai Capitalisme. ${ }^{5}$

\section{b. Sosialis}

Sosialisme sebagai gerakan ekonomi muncul sebagai perlawanan terhadap ketidak adilan yang timbul dari sistem kapitalisme.John Stuart Mill (1806-1873), menyebutkan sebutan sosialisme menunjukkan kegiatan untuk menolong orang-orang yang tidak beruntung dan tertindas dengan sedikit tergantung dari bantuan pemerintah.

Sosialisme juga diartikan sebagai bentuk perekonomian di mana pemerintah paling kurang bertindak sebagai pihak dipercayai oleh seluruh warga masyarakat, dan menasionalisasikan industri-industri besar dan strategis seperti pertambangan, jalanjalan, dan jembatan, kereta api, serta cabang-cabang produk lain yang menyangkut 
hajat hidup orang banyak. Dalam bentuk yang paling lengkap sosialisme melibatkan pemilikan semua alat-alat produksi, termasuk di dalamnya tanah-tanah pertanian oleh negara, dan menghilangkan milik swasta. ${ }^{6}$

\section{c. Komunis}

Komunisme muncul sebagai aliran ekonomi, ibarat anak haram yang tidak disukai oleh kaum Kapitalis. Aliran ekstrim yang muncul dengan tujuan yang sama dengan sosialisme, sering lebih bersifat gerakan ideologis dan mencoba hendak mendobrak sistem kapitalisme dan sistem lain yang telah mapan. Kampiun Komunis adalah Karl Marx, sosok yang amat membenci Kapitalisme ini merupakan korban dan saksi sejarah, betapa ia melihat para anak-anak dan wanita-wanita -termasuk keluarganya- yang di eksploitir para kapitalis sehingga sebagian besar dari mereka terserang penyakit TBC dan tewas, karena beratnya penderitaan yang mereka alami. Sementara hasil jerih payah mereka dinikmati oleh para pemilik sumber daya (modal) yang disebutnya kaum Bourjuis.

Kata Komunisme secara historis sering digunakan untuk menggambarkan sistem-sistem sosial di mana barang-barang dimiliki secara bersama-sama dan didistribusikan untuk kepentingan bersama sesuai dengan kebutuhan masing-masing anggota masyarakat. Produksi dan konsumsi bersama berdasarkan kapasitas ini merupakan hal pokok dalam mendefinisikan paham komunis, sesuai dengan motto mereka: from each according to his abilities to each according to his needs (dari setiap orang sesuai dengan kemampuan, untuk setiap orang sesuai dengan kebutuhan). ${ }^{7}$

\section{d. Fasisme}

Ilmu ekonomi merupakan ilmu yang mempelajari masyarakat dalam usahanya untuk mencapai kemakmuran dalam suatu keadaan dimana manusia dapat memenuhi kebutuhannya, baik barang maupun jasa. ${ }^{8}$ Untuk memenuhi kebutuhan tersebut muncullah suatu prinsip ekonomi Fasisme dari filsafat radikal yang muncul dari revolusi industri yakni sindikalisme. Eksponen sindikalisme adalah George Sorel (1847-1922). Para penganjur sindikalisme menginginkan reorganisasi masyarakat menjadi: asosiasi-asosiasi yang mencakup seluruh industri, atau sindikatsindikat pekerja. Dalam praktik Fasisme dan Komunisme adalah dua gejala dari penyakit yang sama. Keduanya sering dikelompokkan sebagai sistem totaliter. Keduanya sama dalam hal pemerintahan, yaitu kediktatoran satu partai. ${ }^{9}$

\section{Ekonomi Islam}


Sistem ekonomi Islam mendorong kehidupan manusia sebagai kesatuan yang utuh dan menolong kehidupan seseorang sebagai bagian yang tidak terpisahkan dari kehidupan masyarakat, yang individu-individunya saling membutuhkan dan saling melengkapi dalam sekema tata sosial, karena manusia adalah entitas individu sekaligus kolektif. Selain itu ekonomi Islam mengedepankan sebuah konsep Hablum min-Allah wa hablum min-Annas, yang berkaitan tentang tuhan, manusia dan hubungan keduanya. Karena Islam yakin bahwa stabilitas universal tergantug pada kesejahteraan material dan sepiritual manusia.

Islam bukan sekedar menawarkan pedoman-pedoman moral teoritis guna membangun sistem ekonomi, tapi juga mengemukakan suatu metodologi yang layak untuk menerapkan pedoman-pedoman dengan ke absahan cara dan juga legitimasi tujuan dengan landasan atas pertimbangan etika yang jelas dan dapat bemakna di dalam keseluruan kerangka tata sosial, dengan pendekatan terhadap system ekonomi ini sangat relevan dan amat mendesak untuk di alamatkan pada syari'ah dengan sistem ekonomi islam. $^{10}$

Dalam sistem kapitalis yang dikedepankan adalah keuntungan dan Tuhan dipensiunkan (retired God). Hal ini direfleksikan dalam konsep "laissez faire" dan "invisible hand". Dari falsafah ini kita bisa melihat tujuan ekonomi kapitalis hanya sekadar pertumbuhan ekonomi dangan mencari keuntungan. Asumsinya dengan pertumbuhan ekonomi setiap individu dapat melakukan kegiatan ekonomi demi tercapainya kepuasan individu. Berbeda dengan sistem ekonomi Islam yang mengedepankan nilai-nilai ketuhanan yang dimana Falsafah ekonimi Islam secara umum dapat dilihat dari surat al-Muthaffifin ayat 1 sampai 6. Allah berfirman: 1) Kecelakaan besarlah bagi orang-orang yang curang. 2) (Yaitu) orang-orang yang apabila menerima takaran dari orang lain mereka minta dipenuhi. 3) Dan apabila mereka menakar atau menimbang untuk orang lain, mereka mengurangi. 4) Tidaklah orang-orang itu menyangka, bahwa Sesungguhnya mereka akan dibangkitkan. 5) Pada suatu hari yang besar. 6) (Yaitu) hari (ketika) manusia berdiri menghadap Tuhan semesta alam.

Dalam sistem ekonomi konvensional melihat ilmu ekonomi sebagai suatu yang sekuler (berorientasi hanya pada kehidupan duniawi kini dan disini), sementara itu ekonomi Islam justru dibangun atas, atau paling tidak diwarnai oleh prinsip-prinsip relijius (berorientasi pada kehidupan dunia- kini dan sini-dan sekaligus kehidupan akhirat nanti dan disana). ${ }^{11}$ 
Dalam Islam, kesejahteraan sosial dapat dimaksimalkan jika sumber daya ekonomi dapat dialokasikan sedemikian rupa, dengan sistem ekonomi yang dibangun dengan pondasi syariah yang di atur dalam kerangka Al-Qur'an atau Sunnah, tidak ada seorang pun lebih baik dengan menjadikan orang lain lebih buruk. ${ }^{12}$ Bila dilihat antara sistem ekonomi Islam dengan sistem ekonomi konvensional terdapat beberapa perbedaan dilihat dari sifat dan volumenya. Perbedaan yang mendasar ada dari beberapa sudut pandang, yaitu : ${ }^{13}$

a. Sumber (Epistemology), yang berdasarkan sumber yang mutlak yaitu Al-Quran dan As-Sunnah.

b. Tujuan Kehidupan, mengandung konsep al-falah (kejayaan) didunia dan ahirat.

Jadi dapat ditarik kesimpulkan menurut perinsip ekonomi Islam dapat dibagi dua yaitu $:^{14}$

1. Prinsip ekonomi yang bersifat kewahyuan, prinsip ini diambil dari Al-Qur'an dan hadis.

2. Prinsip ekonomi bukan wahyu, prinsip ekonomi yang diambil dari rasio dan observasi.

Didalam ekonomi Islam didasarkan pada lima prinsip dasar universal dalam membangun teori-teori ekonomi Islam, yaitu :

1. Tauhid, Merupakan Pondasi ajaran Islam.

2. Keadilan, sebagai ajaran universal

3. Nubuwah, menempatkan nabi Muhammad Sebagai teladan dalam berbagai aktivitas.

4. Khilafah, menjaga pelaku ekonomi untuk menjaga keteraturan interaksi (mu'amalah).

5. Ma'ad, kebangkitan dan kembali dalam kontek ekonopmi Islam. ${ }^{15}$

Dan didalam ekonomi islam juga mempunyai beberapa karakteristik, sebagai berikut $:^{16}$

1. Harta Kepunyaan Allah dan Manusia merupakan khalifah atas harta,

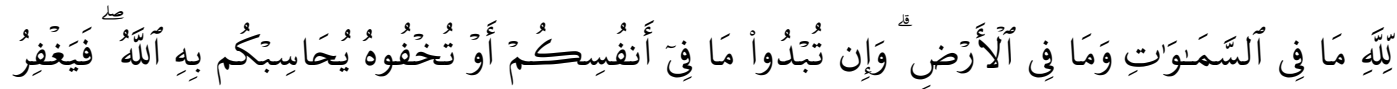

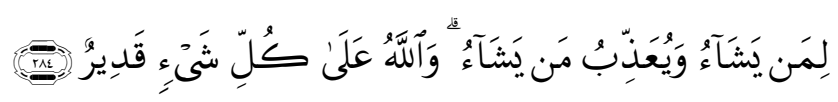

kepunyaan Allah-lah segala apa yang ada di langit dan apa yang ada di bumi. dan jika kamu melahirkan apa yang ada di dalam hatimu atau kamu menyembunyikan, niscaya Allah akan membuat perhitungan dengan kamu tentang perbuatanmu itu. Maka Allah mengampuni siapa yang dikehandaki-Nya dan menyiksa siapa yang dikehendaki-Nya; dan Allah Maha Kuasa atas segala sesuatu. 
2. Ekonomi Terikat dengan Akidah, Syariah dan Moral.

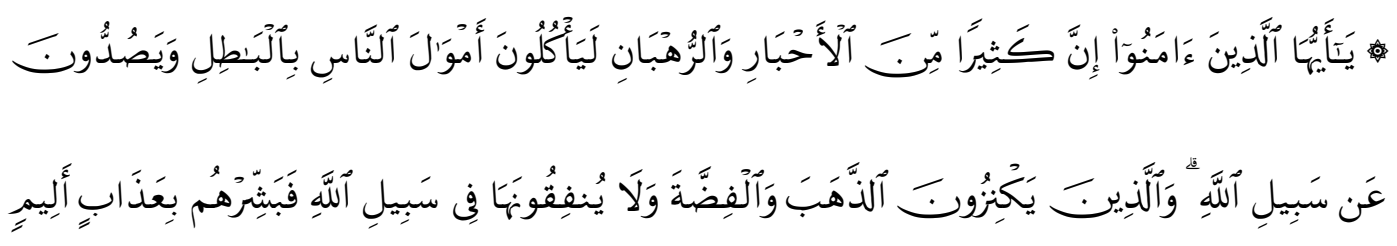

Hai orang-orang yang beriman, Sesungguhnya sebahagian besar dari orangorang alim Yahudi dan rahib-rahib Nasrani benar-benar memakan harta orang dengan jalan batil dan mereka menghalang-halangi (manusia) dari jalan Allah. dan orang-orang yang menyimpan emas dan perak dan tidak menafkahkannya pada jalan Allah, Maka beritahukanlah kepada mereka, (bahwa mereka akan mendapat) siksa yang pedih.

3. Keseimbangan antara kerohanian dan kebendaan.

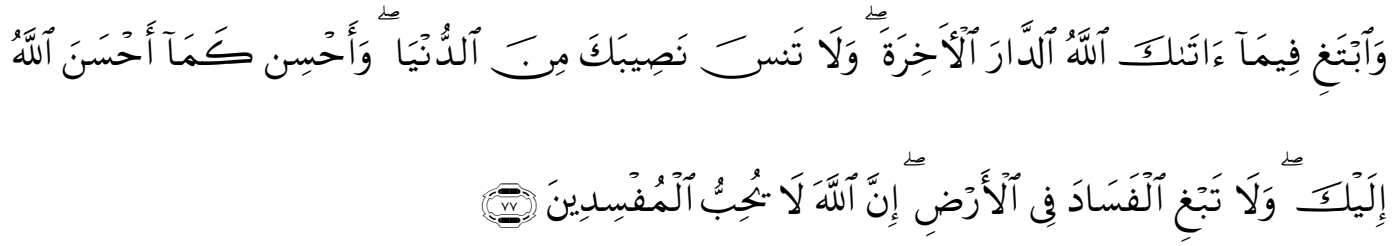

dan carilah pada apa yang telah dianugerahkan Allah kepadamu (kebahagiaan) negeri akhirat, dan janganlah kamu melupakan bahagianmu dari (kenikmatan) duniawi dan berbuat baiklah (kepada orang lain) sebagaimana Allah telah berbuat baik, kepadamu, dan janganlah kamu berbuat kerusakan di (muka) bumi. Sesungguhnya Allah tidak menyukai orang-orang yang berbuat kerusakan.

4. Ekonomi Islam Menciptakan keseimbangan antara kepentingan individu dengan kepentingan umum.

Ekonomi Islam Menciptakan keseimbangan seperti halnya dalam penetapan harga dalam suatu pasar. Harga yang tepat adalah harga yang sesuai dengan kualitas produk suatu barang, dan harga tersebut dapat memberikan kepuasan kepada konsumen.

Menurut ekonomi kapitalis dalam penentuan harga dibentuk oleh keadaan supply and demand. Karena pasar bebas ini akan menghasilkan keseimbangan dalam masyarakat yang nantinya akan menghasilkan upah yang adil, harga yang stabil, dan tingkat pengangguran yang rendah. Sedangkan pada konsep ekonomi sosialis negara harus 
menguasai segala sektor ekonomi untuk memastikan keseimbangan dan keadilan ekonomi dipasar. Didalam ekonomi Islam memandang pasar dijamin kebebasannya, dimana pasar dibiarkan berjalan sendiri tanpa ada yang mengontrol yang menyebabkan penguasa pasar sepihak. Pasar bebas menentukan cara berproduksi dan harga tidak boleh ada gangguan yang mengakibatkan rusaknya keseimbangan pasar. Yang kenyataannya pasar tidak dapat bejalan sendiri secara adil (fair), sehingga dapat merugikan berbagai pihak. Oleh karena itu didalam penentuan harga di pasar sesuai dengan kekuatan penawaran dan permintaan dipasar, dan harga barang tidak boleh ditetapkan pemerintah, karena ketentuan harga tergantung pada hukum supply and demand.

Ada sejumlah cara dalam menetapkan harga, diantaranya adalah :

1. Strategi perusahaan dan komponen-komponen lain didalam bauran pemasaran.

2. Perluasan produk sedemikian rupa sehingga produk dipandang berbeda dari produk-produk lain yang bersaing dalam mutu atau tingkat pelayanan konsumen.

3. Biaya dan harga pesaing.

4. Ketersediaan dan harga dari produk pengganti. ${ }^{17}$

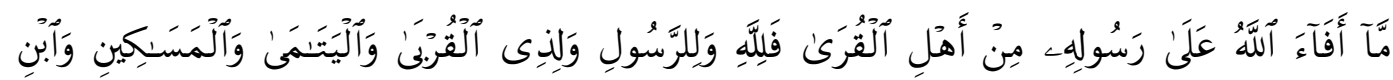

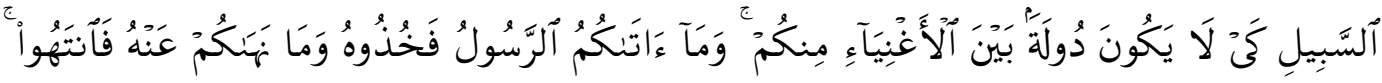

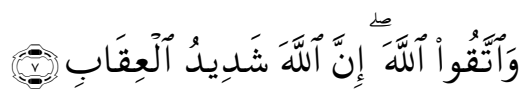

apa saja harta rampasan (fai-i) yang diberikan Allah kepada RasulNya (dari harta benda) yang berasal dari penduduk kota-kota Maka adalah untuk Allah, untuk rasul, kaum kerabat, anak-anak yatim, orang-orang miskin dan orang-orang yang dalam perjalanan, supaya harta itu jangan beredar di antara orang-orang Kaya saja di antara kamu. apa yang diberikan Rasul kepadamu, Maka terimalah. dan apa yang dilarangnya bagimu, Maka tinggalkanlah. dan bertakwalah kepada Allah. Sesungguhnya Allah Amat keras hukumannya.

5. Kebebasan individu dijamin dalam Islam

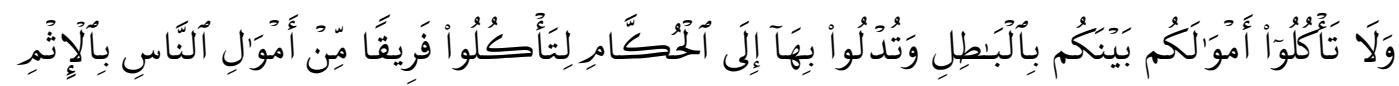


dan janganlah sebahagian kamu memakan harta sebahagian yang lain di antara kamu dengan jalan yang bathil dan (janganlah) kamu membawa (urusan) harta itu kepada hakim, supaya kamu dapat memakan sebahagian daripada harta benda orang lain itu dengan (jalan berbuat) dosa, Padahal kamu mengetahui.

6. Negara diberi wewenang turut campur dalam perekonomian, Islam memperkenankan negara mengatur masalah perekonomian, hal ini sesuai dengan sabda Rasulullah saw yang artinya :'Barang siapa yang meninggalkan beban, hendaklah ia datang kepadaku, karena akulah maula (pelindungnya)".(al-mustakrak oleh Al-Hakim).

7. Bimbingan Konsumsi

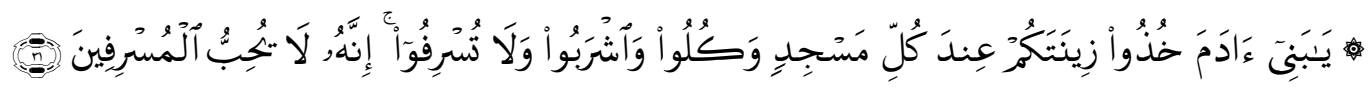

Hai anak Adam, pakailah pakaianmu yang indah di Setiap (memasuki) mesjid, Makan dan minumlah, dan janganlah berlebih-lebihan. Sesungguhnya Allah tidak menyukai orang-orang yang berlebih-lebihan.

8. Petunjuk Investasi, yang diman islam menjadikan pedoman dalam berinvestasi sebagai berikut :

- Proyek yang baik menurut Islam

- Memberikan rezeki seluas mungkin pada anggota masyarakat

- Memberantas kekapiran

- Memelihara dan menumbuh kembangkan harta

- Melindungi kepentingan anggota masyarakat

9. Zakat, sebagai pembersih jiwa dari sifat kikir, dengki dan dendam.

10. Larangan riba

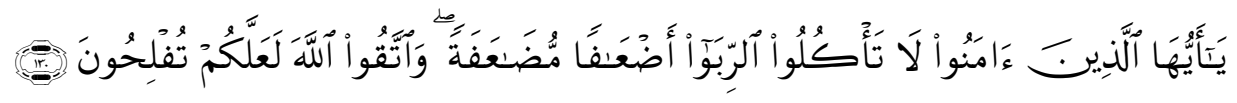

Hai orang-orang yang beriman, janganlah kamu memakan Riba dengan berlipat ganda dan bertakwalah kamu kepada Allah supaya kamu mendapat keberuntungan.

Adapun ketangguhan sistem keuangan Islam, antara lain :

1. Menggerakkan Ekonomi Riil, Ekonomi Islam tidak mengenal dualisme ekonomi yaitu ekonomi yang terdiri dari sektor riil dimana Ekonomi Islam 
didasarkan pada ekonomi riil yang memastikan perputaran harta kekayaan tetap berputar secara luas.

2. Menciptakan Stabilitas Keuangan Dunia, sistem keuangan Islam (mata uang Islam dinar dan dirham, larangan riba dan penerapan ekonomi berbasis sektor riil yang melarang spekulatif di pasar keuangan derivatif) akan tercipta stabilitas keuangan dunia.

3. Tidak Menzalimi, menerapkan syariah Islam yang akan menghidupkan kita dalam kehidupan yang indah, aman dan menenteramkan dalam limpahan keberkahan Allah. ${ }^{18}$

\section{Syarat berhasilnya suatu ekonomi}

Ekonomi memberikan gambaran tentang corak dan ruang lingkup analisis ekonomi, ekonomi selalu dihubungkan dengan keadaan ketidak seimbangan diantara kemampuan faktor-faktor produksi untuk menghasilkan barang dan jasa serta keinganan masyarakat untuk mendapatkan barang dan jasa.

Berbagai ahli mengadatakan ilmu ekonomi adalah suatu studi mengenai individuindividu dan masyarakat yang membuat pilihan dengan atau tanpa penggunaan uang, dengan mengunakan sumber-sumber daya yang terbatas, tetapi dapat dipergunakan dalam berbagai cara untuk menghasilkan berbagai jenis barang dan jasa dan mendistribusikannya untuk kebutuhan konsumsi sekarang dan dimasa yang akan datang, kepada berbagai individu dan golongan masyarakat. ${ }^{19}$

Sistem ekonomi yang diterapkan oleh Rasulullah SAW berakar dari prinsipprinsip qur'ani. Dalam Islam, kehidupan manusia tidak dapat dipisahkan antara dunia dan akhirat, keduanya merupakan satu kesatuan. Begitu juga dengan kehidupan manusia, Allah SWT tidak memerintahkan manusia untuk memisahkan kehidupannya antara dunia dan akhirat. Dalam rangka megemban amanah sebagai khalifah, manusia diberi kebebasan untuk mencari nafkah sesuai dengan hukum yang berlaku serta dengan cara yang adil. Islam mengakui kepemilikan pribadi, alat-alat produksi, barang dagangan, tetapi hanya melarang perolehan kekayaan melalui cara-cara yang ilegal atau tidak bermoral.

Sejalan dengan adanya suatu perekonomian. Untuk lebih berkembangnya suatu perekonomian perlu adanya suatu kebijakan-kebijakan yang diadakan oleh pemerintah, baik itu tindakan maupun strategi supaya ekonomi yang sedang berjalan diupayakan terus maju, tanpa adanya suatu kelemahan ekonomi yang mengakibatkan terjadinya inflasi, pengangguran dan lain sebagainya. Tetapi apabila pendapatan pemerintah berkurang 
maka pemerintah juga harus mengurangi pengeluaran. Singkatnya orang berpandangan bahwa pemerintah haruslah menjalankan kebijakan fiskal seimbang atau anggaran belanja seimbang, yaitu pengeluaran haruslah sesuai atau sama dengan pendapatanya.

\section{Ketangguhan Ekonomi Islam dalam perekonomian Dunia}

Pada saat sekarang ini sedang berkembang konsep perbankan syari'ah. Ada 170 bank yang melakukan usaha dengan sistem bagi hasil, dengan perincian 6 bank umum syari'ah (BUS), 25 unit usaha syari'ah (UUS), dan 139 Bank Perkreditan Rakyat Syari'ah (BPRS) (BI, 2009). Perbankan syari'ah diatur dengan UU No.21 tahun 2008. Menurut fenoma bahwa dengan menggunakan prinsip syari'ah laporan tidak begitu berpengaruh pada masa krisis, terutama pada masa 1997/1998 dan 2008 yang lalu. Ini juga diakui oleh Bank Indonesia dalam laporan tahunannya mengatakan: "di tengah-tengah krisis keuangan global yang melanda dunia pada penghujung akhir tahun 2008, lembaga keuangan syariah kembali membuktikan daya tahannya dari terpaan krisis. Lembagalembaga keuangan syariah tetap stabil dan memberikan keuntungan, kenyamanan serta keamanan bagi para pemegang sahamnya, pemegang surat berharga, peminjam dan para penyimpan dana di bank-bank syariah.

Hal ini dapat dibuktikan dari keberhasilan bank Muamalat melewati krisis yang terjadi pada tahun 1998 dengan menunjukkan kinerja yang semakin meningkat dan tidak menerima sepeser pun bantuan dari pemerintah dan pada krisis keuangan tahun 2008, bank Muamalat bahkan mampu memperoleh laba Rp. 300 miliar lebih.

Ditambahkan lagi penjelasan oleh Bank Indonesia mengatakan bahwa "Perbankan syariah sebenarnya dapat menggunakan momentum ini untuk menunjukkan bahwa perbankan syariah benar-benar tahan dan kebal krisis dan mampu tumbuh dengan signifikan. Oleh karena itu perlu langkah-langkah strategis untuk merealisasikannya". ${ }^{20}$

Dalam konsepsi Islam, orientasi ekonomi haruslah memperjuangkan nasib rakyat kecil serta kesejahteraan rakyat banyak, yang dalam teori ushul fiqh dinamakan al maslahah al ammah. Sedangkan mekanisme yang digunakan untuk mencapai kesejahteraan itu tidaklah ditentukan format dan bentuknya. Oleh karena itu, sistem kapitalisme yang tidak bertentangan dengan Islam, dapat dijadikan rujukan dalam pengambilan kebijakan dalam penanggulangan inflasi dengan kebijakan - kebijakan Pemerintah yang digunakan untuk mengatasi masalah inflasi:

a. Kebijakan fiskal, Kebijakan ini dilaksanakan dalam bentuk mengurangi pengeluaran pemerintah, langkah ini menimbulkan efek yang cepat dalam mengurangi pengeluaran dalam perekonomian. ${ }^{21}$ 
b. Kebijakan moneter, peraturan dan ketentuan yang dikeluarkan oleh otoritas moneter untuk mengendalikan jumlah uang yang beredar. ${ }^{22}$ Seperti halnya yang dilakukan masa khalifah Umar ibn Khattab, kafilah pedagang yang menjual barangnya di luar negeri membeli barang-barang dari luar negeri lebih sedikit nilainya daripada nilai barang-barang yang mereka jual, sehingga mereka mendapat keuntungan. Keuntungan yang berupa kelebihan uang tersebut dibawa masuk ke Madinah sehingga pendapatan dan daya beli masyarakat akan naik (AD $\uparrow$ ). Naiknya Permintaan Agregat akan membuat kurva AD bergeser ke kanan dan akan mengakibatkan naiknya tingkat harga secara keseluruhan $(\mathrm{P} \uparrow)$. Kemudian, yang dilakukan oleh Umar ibn Khattab dalam mengatasi masalah tersebut adalah beliau melarang penduduk Madinah untuk membeli barang-barang selama 2 hari berturut-turut. Akibatnya, adalah turunnya Permintaan Agregat $(\mathrm{AD} \downarrow)$ dan tingkat harga menjadi normal.

c. Peningkatan Produksi, Meski jumlah uang beredar bertambah jika di iringi dengan peningkatan produksi, maka tidak akan menyebabkan inflasi. Bahkan hal ini menunjukkan adanya peningkatan kemampuan ekonomi.

d. Kebijakan Upah, Inflasi dapat diatasi dengan menurunkan pendapatan yang siap dibelanjakan (disposable income) masyarakat.

e. Pengawasan Harga, Kecenderungan dinaikkannya harga oleh pengusaha dapat diatasi dengan adanya pengawasan harga pasar.

f. Perbaikan Prilaku Masyarakat,

Sedangkan setidaknya ada tujuh kebijakan moneter Islam yang dapat mengendalikan inflasi baik secara langsung maupun tidak langsung, yaitu: ${ }^{23}$

a. Dinar dan dirham sebagai mata uang,

b. Hukum jual beli mata uang asing,

c. Hukum pertukaran mata uang,

d. Hukum bunga, hukum pasar modal,

e. Hukum perbankan,

f. Hukum pertukaran internasional, dan

g. Otoritas kebijakan moneter

Untuk memudahkan analisa permasalahan pengendalian inflasi dalam perspektif kebijakan moneter Islam, maka penulis terlebih dahulu akan mendefenisikan suatu pengaturan di bidang moneter yang bertujuan untuk menjaga dan memelihara kestabilan nilai uang dan mendorong kelancaran produksi dan pembangunan dalam rangka meningkatkan taraf hidup masyarakat. ${ }^{24}$ Jadi dapat disimpulkan kebijakan moneter merupakan sebuah proses yang dilakukan oleh pemerintah, bank sentral, 
atau otoritas moneter dari sebuah negara untuk mengontrol, penawaran uang, ketersediaan uang, tingkat bunga, dalam rangka mencapai seperangkat tujuan orientasi kepada pertumbuhan dan stabilitas ekonomi.

\section{Kesimpulan}

Sistem Ekonomi Islam adalah perekonomian yang berbasis sektor riil (lihat al-Baqarah: 275). Tidak ada dikotomi antara sektor riil dengan sektor moneter. Sebab sektor moneter dalam Islam bukan seperti sektor moneter Kapitalis yang isinya sektor maya (virtual sector). Islam memandang kegiatan ekonomi hanya terdapat dalam sektor riil seperti pertanian, industri, perdagangan, dan jasa. Dari sektor inilah kegiatan ekonomi didorong untuk berkembang maju. Hanya saja hukum-hukum tentang kepemilikan, produk (barang/jasa), dan transaksi dalam perekonomian Islam berbeda dengan Kapitalis.

Ekonomi Islam merupakan solusi bagi umat manusia untuk keluar dari krisis dan hidup sejahtera, disamping itu ekonomi Islam menawarkan satu sistem ekonomi Islam yang dibangun di atas pondasi akidah Islam. Dan aktivitas ekonomi ini bisa menjadi bagian dari aktivitas ibadah, dimana aktivitas yang dilakukan tidak hanya mencari penghasilan demi menyambung kelangsungan hidup, melaikan juga sebagai panggilan mulia ajaran agama. Ini adalah akidah yang haq karena berasal dari Allah yang dibawa kepada umat manusia melalui Muhammad Rasulullah SAW. Akidah Islam merupakan akidah yang memuaskan akal, menenteramkan jiwa, dan sesuai dengan fitrah manusia. Karenanya peraturan yang terpancar dari akidah Islam seperti sistem ekonomi Islam memiliki karakter yang khas dan manusiawi. Ekonomi Islam juga termuat dalam lebih dari seperlima ayat-ayat yang dimuat dalam Al-Quran, yang tidak mengarah pada Kapitalisme maupun Sosialisme. Jika Kapitalisme menonjolkan sifat individualisme dari manusia, dan Sosialisme pada kolektivisme, maka Islam menekankan empat sifat sekaligus yaitu :

\section{Kesatuan (unity)}

2. Keseimbangan (equilibrium)

3. Kebebasan (free will)

4 .Tanggungjawab (responsibility)

Hal inilah yang dilihat oleh para pelaku ekonomi konvensional sehingga bondong-bondong beralih pada ekonomi Islam dan vatikan juga tidak ketinggalan menawarkan prinsip-prinsip keuangan Islam kepada bank-bank di Barat, yang sekarang 
menghadapi krisis, dan sebagai alternative bagi sistem kapitalisme. Ekonomi Islam merupakan solusi bagi umat manusia untuk keluar dari krisis dan hidup sejahtera, disamping itu sistem ekonomi ini bisa juga sebagai bentuk penyiaran agama islam. Yang dimana dalam sistem ekonomi islam ini diatur dalam Al-Qur'an dan Hadist. Untuk itu kita membutuhkan Khilafah Islamiyah sebagai institusi yang menerapkan ekonomi Islam.

\section{Endenotes}

${ }^{1}$ Dumairy, Perekonomian Indonesia, (Jakarta : Erlangga, 1996), hal. 30.

${ }^{2}$ Euis Amalia. Sejarah Pemikiran Ekonomi Islam, (Jakarta: Gramata Publishing, 2005), hal. 2.

${ }^{3}$ Ibid.

${ }^{4}$ Robert L. Heilbroner, Tokoh-Tokoh Besar Pemikir Ekonomi, (Jakarta: UI Press, 1986), hal 255.

${ }^{5}$ Sadono Sukirno, Pengantar Ekonomi Mikro, (Jakarta: Rajawali Perss, 1999), hal. 3 .

${ }^{6}$ Winardi, 1986, Kapitalisme Versus Sosialisme, Remadja Karya : Bandung.

${ }^{7}$ Deliarnov, 1995, Perkembangan Pemikiran Ekonomi, Raja Garfindo Persada : Jakarta.

${ }^{8}$ Elsi Kartika Sari, 2007, Hukum dalam Ekonomi, PT. Grasindo, Jakarta, hal. 4

${ }^{9} \mathrm{http} / / /$ bagusramadhan.ngeblogs.com/sistem-perekonomian/2009/11/16/

${ }^{10} \mathrm{http}: / /$ alam-berzdikir.blogspot.com/2012/05/20

${ }^{11}$ Adiwarman A.Karim, 2008, Ekonomi Mikro Islam, Rajawali Press: Jakarta, hal.29-30.

12 Muhamad, 2008, Metodologi Penelitian Ekonomi Islam: Pendekatan Kuantitatif, Rajawali Perss: Jakarta, hal.29.

${ }_{13}$ Mustafa Edwin Nasution, 2006, Pengenalan Eksklusif : ekonomi Islam, Kencana: Jakarta, hal. 8-10.

14 Azhari Akmal Tarigan, 2007, Dasar-DasarEkonomi Islam, Cipta Pustaka Media: Bandung, hal.74-75.

15 Adiwarman A.Karim, 2008, Ekonomi Mikro Islam, Rajawali Press: Jakarta, hal.35-41.

16 Mustafa Edwin Nasution, 2006, Pengenalan Eksklusif : ekonomi Islam, Kencana: Jakarta, hal. 18-31.

${ }_{17}^{17}$ http://www.e-iman.uni.cc/2009/12/01/

demokrasi.htm /28/08/2009/.

18 http://www.WordPress.com/ menyongsong peradaban baru tanpa

${ }^{19}$ Sadono sukirno, Mikro ekonomi, (Jakarta: Rajawali Pers, 1999), hal 10.

${ }^{20} \mathrm{http} . / /$ Bank Indonesia.co.id

${ }^{21}$ Sadono sukirno, Mikro ekonomi, (Jakarta: Rajawali Pers, 1999), hal 423.

${ }^{22}$ N.Gregory Mankiw, Makro Ekonomi ,(Jakarta: Erlangga, 2007), hal 396-414

${ }^{23}$ M. Hatta, Telaan Singkat dalam pengendalian inflasi dalam perfektif kebijakan moneter Islam, Junal Ekonomi Ideologis, Edisi Juni 2008.

${ }^{24}$ Aulia Pohan. Potret Kebijakan Moneter Indonesia, cet. I (Jakarta; Rajawali Pers, 2008), hal. 11 


\section{DAFTAR PUSTAKA}

Amalia, Euis. Sejarah Pemikiran Ekonomi Islam, (Jakarta: Gramata Publishing, 2005)

Adiwarman A.Karim, 2008, Ekonomi Mikro Islam, Rajawali Press: Jakarta

Akmal Tarigan, Azhari, 2007, Dasar-DasarEkonomi Islam, Cipta Pustaka Media: Bandung,

Dumairy, Perekonomian Indonesia, (Jakarta : Erlangga, 1996), hal. 30.

Deliarnov, 1995, Perkembangan Pemikiran Ekonomi, Raja Garfindo Persada : Jakarta.

Edwin Nasution, Mustafa, 2006, Pengenalan Eksklusif : ekonomi Islam, Kencana: Jakarta,

Hatta, M.Telaan Singkat dalam pengendalian inflasi dalam perfektif kebijakan moneter Islam, Junal Ekonomi Ideologis, Edisi Juni 2008.

Kartika Sari, Elsi, 2007, Hukum dalam Ekonomi, PT. Grasindo, Jakarta

Muhamad, 2008, Metodologi Penelitian Ekonomi Islam: Pendekatan Kuantitatif, Rajawali Perss: Jakarta,

N. Gregory Mankiw, Makro Ekonomi ,(Jakarta: Erlangga, 2007),

Pohan, Aulia. Potret Kebijakan Moneter Indonesia, cet. I (Jakarta; Rajawali Pers, 2008),

Robert L. Heilbroner, Tokoh-Tokoh Besar Pemikir Ekonomi, (Jakarta: UI Press, 1986)

Sadono Sukirno, Pengantar Ekonomi Mikro, (Jakarta: Rajawali Perss, 1999),

Winardi, 1986, Kapitalisme Versus Sosialisme, Remadja Karya : Bandung

http://bagusramadhan.ngeblogs.com/sistem-perekonomian/2009/11/16/

http://alam-berzdikir.blogspot.com/2012/05/20

http://www.e-iman.uni.cc/2009/12/01/

http://www.WordPress.com/ menyongsong peradaban baru tanpa demokrasi.htm /28/08/2009/.

http.//Bank Indonesia.co.id 